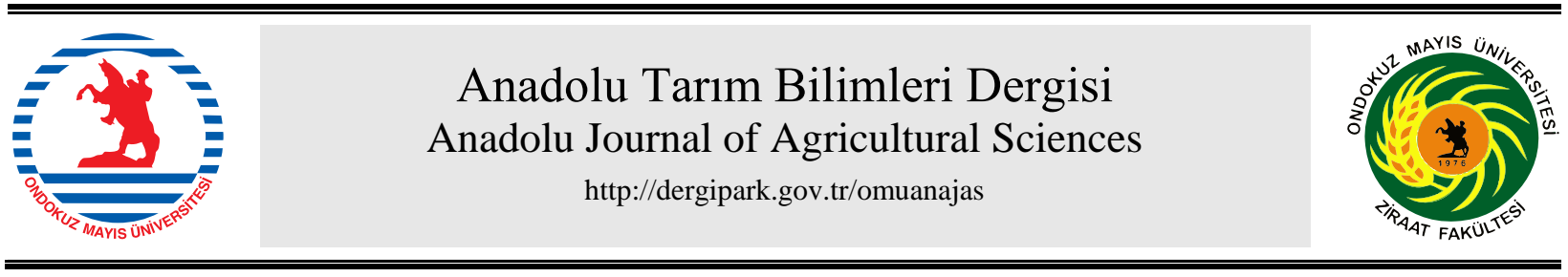

Araştırma/Research

Anadolu Tarım Bilim. Derg./Anadolu J Agr Sci, 33 (2018) ISSN: 1308-8750 (Print) 1308-8769 (Online) doi: 10.7161/omuanajas.401431

\title{
Türkiye'de ana ürün olarak yetiştirilecek soyanın (glycine max L.merrill) çok kriterli karar verme yöntemiyle arazi uygunluk analizinin yapılması
}

\author{
Harun Torunlar ${ }^{\mathrm{a}^{*}}$, Ahmet Nedim Nazlıcan ${ }^{\mathrm{b}}$ \\ ${ }^{a}$ Tarla Bitkileri Merkez Araștırma Enstitüsü, Ankara \\ ${ }^{b}$ (Emekli) Doğu Akdeniz Tarımsal Araştırma Enstitüsü Müdürlüğü, Adana \\ *Sorumlu yazar/corresponding author: htorunlar@hotmail.com \\ Geliş/Received 05/03/2018～Kabul/Accepted 20/06/2018
}

\begin{abstract}
ÖZET
Tarım arazilerinde maksimum verim ve kalite, yetiştirilmek istenen bitkilere, en uygun arazilerin seçilmesi ile mümkün olmaktadır. Arazi kavramı toprak, topoğrafya, iklim gibi bir çok farklı unsuru içermektedir. Bu unsurların birlikte değerlendirildiği yöntemler ise başarılı arazi planlamalarını ortaya koymaktadır. Çok kriterli karar verme yöntemi de bu yöntemlerden bir tanesidir. Bu kapsamda yapılan çalışma ile, ana ürün soya bitkisinin yetişebileceği en uygun araziler, iklim, toprak ve topoğrafya kriterleri dikkate alınarak, Çok kriterli karar verme yöntemi ile değerlendirilmiştir. Söz konusu değerlendirmede, her bir kriterin, arazi uygunluk sınıflarının tespitinde, yapacağı ağırlıklı etki, Analitik Hiyerarşi Süreci Tekniği ile gerçekleştirilmiştir. Ayrıca, bir diğer Çok Kriterli Karar Verme Yöntemi olan, Ağırlıklandırılmış Doğrusal Kombinasyon Yöntemi Kullanılarak da, ana ürün soyanın yetişebileceği arazi uygunluk sınıfları tespit edilmiştir. Buna göre, çalışma alanının \% 22.34 'lük bölümü olan toplam 17435102.53 hektar alan, ana ürün soyanın yetiştirilmesi için çok uygun ve orta uygun sinıflarında yer alırken, \% 15.56 oranında (12 149689.64 ha) alan az uygun, \% 62.10 (48 473 $207.83 \mathrm{ha}$ ) oranındaki alan ise soya yetiştirilmesine uygun olmayan alanlar olarak belirlenmiştir. $\mathrm{Bu}$ sonuçlara göre; en azından çok uygun ve orta uygun sınıfların yer aldığı alanlarda, ana ürün olarak yerli soya üretiminin yapılması, yıllık soya ihtiyacımızın karşılanmasında ithalatın önüne geçeceği düşünülmektedir.
\end{abstract}

Land suitability analysis of main crop soybean (glycine max L. merrill) cultivation in Turkey through the multi criteria decision making method

\begin{abstract}
Maximum productivity and quality in agricultural lands could only be possible through choosing suitable lands for the crops to be cultivated. Suitable land concept encompasses a number of elements including soil, topography and climate. Methods involving the evaluation of all these factors bring about successful land planning. Multi criteria decision making method is one of those methods.

Within this framework, the most suitable lands for main crop soya cultivation was assessed using "multi criteria decision making method" by considering soil, topography and climate criteria, within which Analytical Hierarchy Process (AHP) technique was employed in determining the weighted impact of each criterion. Besides, by employing another multi criteria decision method, the Weighted Linear Combination (WLC) method, land suitability classes where the main crop soya can be cultivated, were determined. According to those assessments, $22.34 \%$ of the study area corresponding to total 17435 102.53 hectare is very and medium suitable for soya cultivation, about $15.56 \%$ (12 149689.64 ha) of the study area is less suitable and about $62.10 \%$ (48 473207.83 ha) of the study area is not suitable. These results suggest that very and mid suitable areas should be used for domestic soya agriculture as the main crop in order to supply annual domestic soya demand to prevent the import.
\end{abstract}

Anahtar Sözcükler: Ana ürün soya Çoklu kriter yöntemi Arazi uygunluk analizi Uygunluk sinıfları

Keywords:

Main crop soya

Multi criteria method Land suitability analysis Suitability classes 


\section{Giriş}

Türkiye nüfusunun yaklaşık yarısı geçimini tarımdan sağlamaktadır. En önemli iç ticaret kaynağımız tarımdır. Milli gelirimizin yaklaşık \%27'si tarımdan sağlanmaktadır. Ekilebilen tarım alanlarının iklim, toprak, topografya gibi farklı ekolojik yapılara sahip olması, yetiştirilen ürün çeşitliliğinin fazla olmasına sebep olmuştur. Bünyesinde bu kadar çok ürün çeşitliliği bulunduran tarım alanlarının üretim potansiyelini artırmak, ülke ekonomisine tarımsal kaynaklardan gelecek olan katkı payını da artıracaktır. Aynı şekilde tarım arazilerinin uygun şekilde yönetiminin sağlanmasına yönelik politikaların geliştirilmesini de sağlayacaktır. $\mathrm{Bu}$ tarım alanlarının etkili yönetimi, tarımsal gelişmede gıda güvenliğinin sağlanması ve sürdürülebilmesi için de esastır. Bir tarım ülkesi olan yurdumuzda yaklaşık 27.5 milyon hektar (ha) tarım yapilabilen (ekilebilen) alan bulunmaktadır (Gençtan, 2009). Bu alanlar içerisinde soya ekimine ayrilan alanlar son y1llar itibariyle istikrarsız dağılış göstermekte olup, 2014 yılı verilerine göre 343.000 dekar alandır (TUIK, 2014). Yağış sorunu yaşanmayan Karadeniz Bölgemizde uzun yıllardan beri tarımı yapılan soya bitkisi, daha sonraları Ege ve Akdeniz Bölgelerimizin sulanır alanlarında da yetiştirilmeye başlanmış olup, bugün özellikle Çukurova Bölgemizden Türkiye soya üretiminin $\% 80$ - 85' karşılanmaktadır. Önemli bir yağ bitkisi olan soya, tohumlarında içerdiği yüksek orandaki protein (\% 4045) ve yağ miktarı (\% 18-20) ile hem insan hem de hayvan beslenmesi açısından büyük önem taşımaktadır (Anonim, 2014). Sanayide hammadde olarak da yaygın bir şekilde kullanılan soya, sağlık açısından vazgeçilmez bir bitki olmasından dolayı son yıllarda çoğu Avrupa ülkesinde üretimi ve tüketimi yaygınlaşmıştır.

FAO-AMIS 2015/16 yılı verilerine göre; Dünya'da soya üretimi 314.5 milyon ton olurken, ülkemizde üretim miktarı 160.000 ton olarak gerçekleşmiştir. Dünya üretiminin 108 milyon tonluk önemli bir kısmını (\% 33.8) ABD, 94.5 milyon tonluk kısmını Brezilya, 60.8 milyon tonluk kismını Arjantin ve 12.3 milyon tonluk kısmını Çin üretirken, ülkemizde bu kadar az ekiliş alanı bulan soyanın, üretim miktarının artırılması için uygun ekiliş alanlarının belirlenmesi gerekmektedir (Anonim, 2015). Ülkemizde ağırlıklı olarak Çukurova Bölgesi illerinde ve Samsun'da 35 - 40 bin hektarlık ekim alanından 150-200 bin tonluk üretimin karşılandığ ve yine her yıl 1.5-2 milyon ton arasında değişen bir soya ithalinin olduğu düşünüldüğünde; ülkemiz için soya ürünleri tüketiminin ortalama 2 milyon ton/y1 civarında seyrettiği anlaşılmaktadır (Anonim, 2014).

Dünya'da sanayileşmenin hızla arttığı bir ortamda, tarım arazilerindeki azalış, canlıların beslenmesi için ihtiyaç duyulan bitkisel ürünlerin daha az üretilmesine sebep olmaktadır. $\mathrm{Bu}$ durum ise mevcut tarım arazilerinden maksimum düzeyde üretim sağlanmasını gündeme taşımaktadır. Bunun için en önemli doğal kaynaklarımızdan biri olan tarım arazilerimizin bilinçli ve planlı bir şekilde değerlendirilmesi gerekmektedir. $\mathrm{Bu}$ da uygun ürünler için uygun alanların belirlenmesi zorunluluğunu gündeme taşımaktadır. Spesifik ürünün tarımı yapilabilecek potansiyel alanlarının belirlenmesinde, ürünün yetişmesi için ihtiyaç duyacağı kriterleri karşılaması ve her bir kriterin, o arazinin, o ürün için tarım yapabilmeye yönelik isteklerine cevap verebilmesi gerekmektedir.

Karmaşık yapıda ve çok sayıda bulunan bu kriterlerin bir arada kullanılmasına, alansal problemlerin çözümlenmesine, modellemesine, değerlendirilmesine ve alternatif öncelik kararların verilmesine sağladığ kolaylıklardan dolayı Coğrafi Bilgi Sistemleri tabanlı (CBS), Çok Kriterli Karar Verme (ÇKKV) yöntemleri kullanılmaktadır (Malczewski, 2006). Çok kriterli değerlendirme süreçleri ülkesel planlamalarda alternatif arazi uygunlukları için potansiyel arazilerin tahmini amacıyla kullanılmaktadır (Chen ve ark., 2008).

CBS ve Çok Kriterli Karar Verme yöntemleri, tarımsal ürünler için arazi uygunluk analizlerinde başarılı bir şekilde kullanılmıştır (Pirbalouti, 2009; He ve ark., 2011; Kihoro ve ark., 2013).

Maddahi ve ark. (2014)'te CBS ve Çok Kriterli Karar Verme yaklaşımını kullanarak İran'ın Amol Bölgesinde, ekonomik öneme sahip olan pirinç tarımı için arazi uygunluk değerlendirmesi yapmışlardır. Çok Kriterli Karar Verme yöntemlerinden Analitik Hiyerarşi Süreç (AHS) tekniğini kullanarak, ürün (pirinç) için seçilen biyofiziksel, sosyo ekonomik ve çevresel faktörler uzman görüşlerine dayalı olarak ağırlıklandırılmış ve bölgenin dört sınıftan oluşan arazi uygunluk sınıflamasını oluşturmuşlardır. Yapılan sınıflamada, alanın \% $6.83\left(20.77 \mathrm{~km}^{2}\right)$ 'ü çok uygun, \% $25.80\left(78.65 \mathrm{~km}^{2}\right)$ 'i uygun, \% $36\left(109.72 \mathrm{~km}^{2}\right)$ 's1 orta uygun ve \% $16.91\left(51.55 \mathrm{~km}^{2}\right)$ 'inin ise uygun olmayan sınıflarda yer aldığını tespit etmişlerdir.

Mustafa ve ark. (2011)'de farklı ürünler için arazi değerlendirme analizlerini yaparlarken, Coğrafi Bilgi Sistemleri ve Uzaktan Algılamayı kullanarak, Çok Kiriterli Karar Verme yaklaşımını yöntem olarak seçmişlerdir. Çalışma Hindistan'ın Agra Bölgesindeki Kheragarah alanında yürütülmüş olup, çalışmada bölgenin yazlık ve kışlık ürün desenini temsilen hardal, şeker kamışı, buğday, arpa, inci darısı, mısır, pamuk, pirinç ve sorgum gibi farklı ürünler seçilmiştir. Ürünler için arazi uygunluk sınıflaması yapılırken, alanın fiziksel ve kimyasal toprak özellikleri olan; toprak reaksiyonu $(\mathrm{pH})$, elektriksel iletkenlik (Ec), organik karbon, yarayışlı azot $(\mathrm{N})$, yarayışlı fosfor $(\mathrm{P})$, yarayışlı potasyum (K), değişebilir sodyum yüzdesi (ESP), saturasyon, katyon değişim kapasitesi (KDK) ve toprak tekstürü gibi çok sayıdaki parametreleri kullanmışlardır. Alan için yazlık ve kışlık dönem ürün uygunluk haritaları oluşturulmuş ve buna göre alanın \% 55'i şeker kamışı için çok uygun, sırasıyla inci darısı, hardal ve pirinç için \% 48, \% 54 ve \% 60 oranlarında orta uygun, mısır için ise \% 50 oranında az uygun alanlar olarak belirlemişlerdir. 
$\mathrm{Bu}$ çalışmada, ana ürün soyanın yetiştirilebilmesi için ihtiyaç duyduğu toprak, topoğrafya ve iklim istekleri parametrelerinin Coğrafi Bilgi Sistemleri kullanılarak Çok Kriterli Karar Verme yöntemine göre ülkesel ölçekte arazi uygunluk sınıflaması yapılmıştır.

\section{Materyal ve Yöntem}

\section{1. Çalışma alanı ve kullanılan veriler}

$\mathrm{Bu}$ çalışma, Türkiye'nin kara sınırlarını içerisine alan ülkesel ölçekte yürütülmüştür. Türkiye, kuzey yarımkürede $35^{\circ} .40^{\prime}-42^{\circ} .06^{\prime}$ kuzey paralelleri ile $25^{\circ} .40^{\prime}-44^{\circ} .48^{\prime}$ doğu meridyenleri arasında yer alır. Etrafı denizlerle çevrili (Akdeniz, Ege Denizi, Marmara Denizi ve Karadeniz) olup iki yarım adadan oluşur. Karasal büyüklük olarak dünyada 37 . sırada yer alıp uluslararası sınırlar ve sahil şeridi ile ayrılmış tüm alanların toplamı yaklaşık olarak $780.580 \mathrm{~km}^{2}$ ' dir (ISO, 3166-1). Ülkenin doğu-batı yönündeki en uzun mesafesi $1600 \mathrm{~km}$, güney - kuzey yönündeki en uzun mesafesi ise 650 km'dir (Şekil 1).

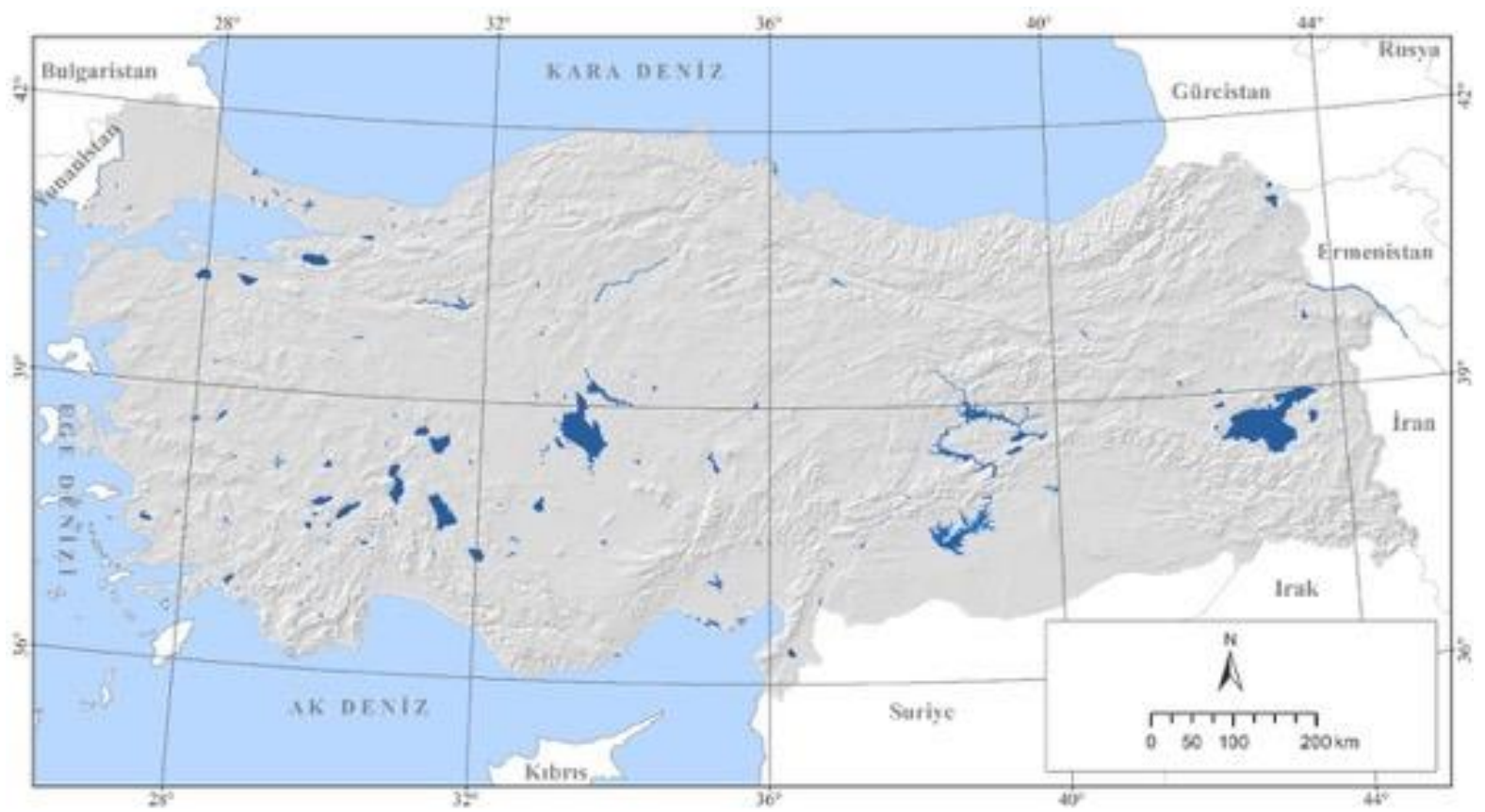

Şekil 1. Çalışma alanı

Tarım yapılabilen alanlar toplam alanının üçte birini oluşturmaktadır. Ortalama yüksekliği deniz seviyesinden 1132 metre'dir. Uzun y1llar (1981-2016) ortalama yağış miktarı $574 \mathrm{~mm}$ olup, yıl içerisinde en fazla yağışı kuzey ve güney bölgeleri alırken en az yağışı orta bölgeler almaktadır (MGM, 2017). Çalışma alanı, subtropikal kuşak içerisinde Akdeniz büyük iklim bölgesinde yer almaktadır (Türkeş, 1998). Büyük kısmı kurak, yarı kurak ve yarı nemli iklim kuşağında yer almakta olup, çalışma alanının yaklaşık \% 65 'ini yarı kurak ve kurak iklim kuşağındaki alanlar kapsamaktadır (ÇEM, 2011).

$\mathrm{Bu}$ çalışmada; Soya bitkisinin arazi uygunluk analizi için ihtiyaç duyduğu ekolojik isteklerden iklim, toprak ve topoğrafya gibi farklı türden veri setleri kullanılmıştır.

İklim veri seti; Meteoroloji Genel Müdürlüğü (MGM) tarafindan, 1975-2012 yılları arasındaki dönemleri kapsayan, ülkesel alan boyutunda dağılım gösteren 270 adet iklim istasyonundan günlük olarak kayıtları tutulmuş olan tablosal verilerden oluşmaktadır.
$\mathrm{Bu}$ veri setini soyanın iklim istekleri olan, vegetasyon süresi, etkili sıcaklık toplamı (EST), Temmuz ve Ağustos ayları ortalama sıcaklık alt kriterleri oluşturmuş̧ur. İklim alt kriterlerinin alana yayılmış yüzey dağılımlarının elde edilmesinde, Hutchinson (1995) interpolasyon metoduna göre çalışan Climap Pertziger ve De Pauw (2002) programı kullanılmıştır.

Topoğrafik veri seti; Arazi yüzeyinin üç boyutlu koordinat kümesi ile temsil edildiği, 90 metre uzaysal çözünürlüğe sahip SRTM (Shuttle Radar Topography Mission) Sayısal Yükseklik Modeli (SYM) kullanılmıştır (Farr, 2000). Bu veri seti soya'nın ihtiyaç duyduğu rakım farkının belirlenmesi amacıyla kullanılmıştır.

Toprak veri seti; Eski adıyla Topraksu Genel Müdürlüğü tarafından, 1966-1971 yılları arasında tüm ülke topraklarının toprak etüd çalışmalarıyla altlık veri olarak 1:25.000 ölçekli topoğrafik haritalar kullanılmak suretiyle oluşturulan ülkesel ölçekte sayısal toprak veri tabanı kullanılmıştır. İçeriğinde Büyük Toprak Grupları (BTG) ile bunların önemli safhalarını esas alan bu veri 
setinden Arazi Kullanım Kabiliyet Sınıfları (AKK) ve soya'nın etkili kök derinliği için derinlik sınıfları, alt kriterler olarak kullanılmıştır.

\subsection{Yöntem}

$\mathrm{Bu}$ çalışmada, ülkesel ölçekte soya bitkisinin yetişmesine uygun olabilecek alanların belirlenmesi için yapılan arazi uygunluk analizinde Çok Kriterli Karar Verme yöntemi kullanılmıştır. Çok Kriterli Karar
Verme yöntemi; birden fazla çok sayıda karmaşık yapıdaki mekansal parametrelerdeki bilgilerin tek bir değerlendirme indeksi oluşturularak nasıl birleştirileceği ile ilgili önceliklerin ortaya konulma sürecidir ( $\mathrm{Yu}$, 2011). ÇKKV yöntemlerinin CBS ile entegrasyonu, güçlü mekansal analiz işlevleri sağlamaktadır $(\mathrm{Yu}$, 2009). Soya için yapılan bu arazi uygunluk analizi yöntemine ait iş akış şeması Şekil 2'de verilmiştir (Kihoro, 2013).

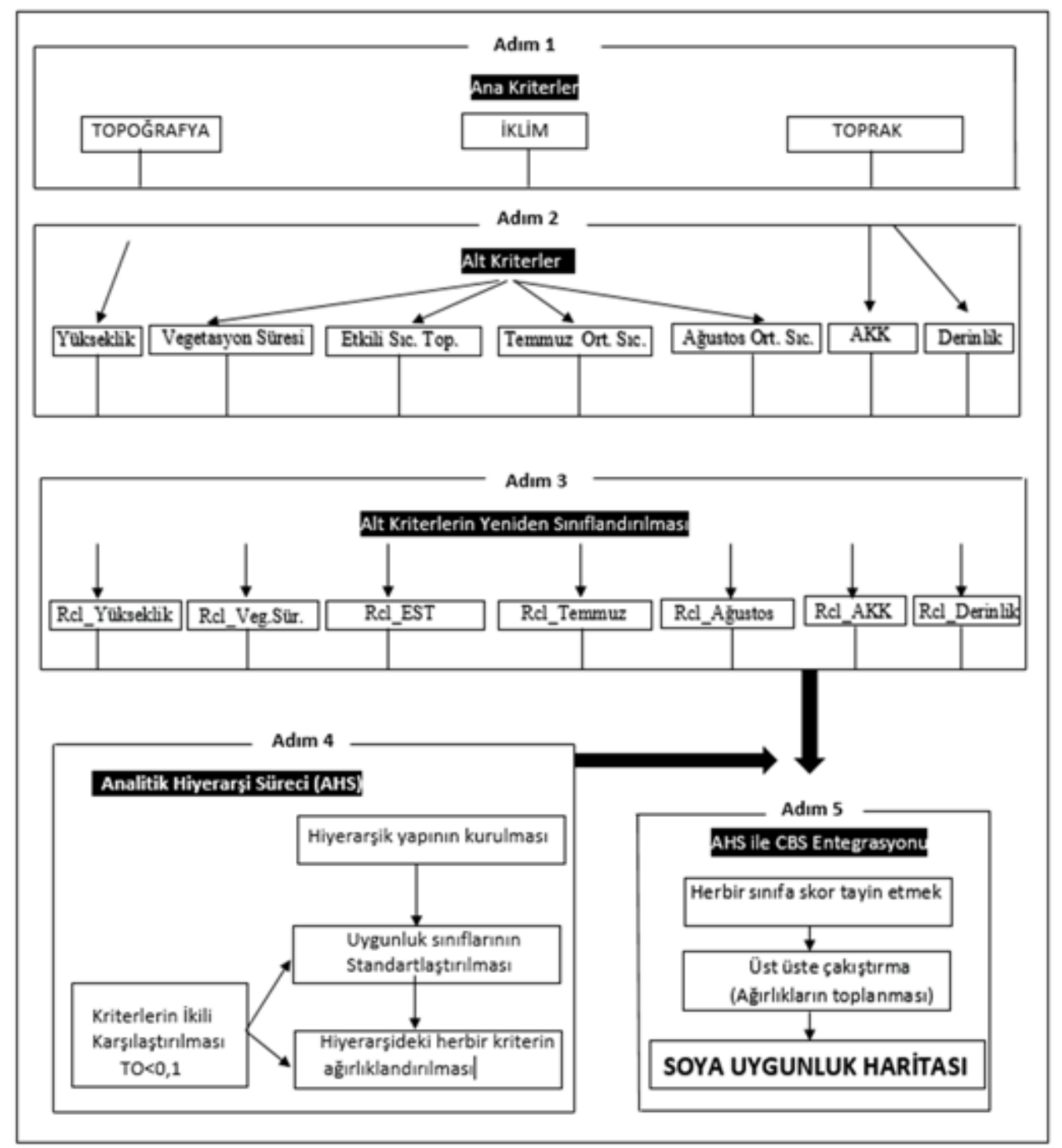

Şekil 2. Ana ürün soya yetiştirilebilir alanlar için arazi uygunluk analizi iş akış şeması

Birden fazla sayıda çok kriterli karar verme yöntemleri bulunmasına rağmen, bu çalışmada bu yöntemlerden biri olan Ağırlıklandırılmış Doğrusal Kombinasyon (Weighted Linear Combination) yöntemi kullanılmıştır (Patrono, 1998). Ağırlıklı doğrusal kombinasyon yöntemi tüm faktörlerin standartlaştırılmasını (Eastman, 1999) ya da daha sonra karşılaştırılabilecek birimler haline dönüştürülmesini zorunlu kılmaktadır (Malczewski, 1999). Ağırlıklı doğrusal kombinasyon yönteminde soya'nın yetişmesine etki eden her bir ana ve alt kriterler için önem derecesine göre bir ağırlık atanmaktadır. Her bir alt kriter için ürün uzmanı görüşleri doğrultusunda alt kriter sınıfları ve bu sınıflara ait standardize edilmiş alt kriter puanları hesaplanmaktadır (Çizelge 1). 
Çizelge 1. Alt kriter sınıf ve ağırlık puanları

\begin{tabular}{|c|c|c|c|c|}
\hline \multirow{4}{*}{ Alt Kriterler } & \multicolumn{4}{|c|}{ Arazi Uygunluk Sınıfları } \\
\hline & $\begin{array}{c}\text { S1 } \\
\text { Çok uygun }\end{array}$ & $\begin{array}{c}\text { S2 } \\
\text { Orta uygun }\end{array}$ & $\begin{array}{c}\text { S3 } \\
\text { Az uygun }\end{array}$ & $\begin{array}{c}\text { S4 } \\
\text { Uygun değil }\end{array}$ \\
\hline & \multicolumn{4}{|c|}{ Alt Kriter Ağırlık Puanları (Skor) } \\
\hline & 4 & 3 & 2 & 1 \\
\hline \multicolumn{5}{|l|}{ İklim } \\
\hline Vejetasyon Süresi (Gün) & $>130$ & $120-130$ & $110-120$ & $<110$ \\
\hline Temmuz Ayı Ortalama Sicaklık ( $\left.{ }^{\circ} \mathrm{C}\right)$ & $>25$ & $22-25$ & $20-22$ & $<20$ \\
\hline Etkili Sıcaklık Toplamı $\left(\geq 10^{\circ} \mathrm{C}\right)$ & $>3000$ & $2500-3000$ & $2000-2500$ & $<2000$ \\
\hline Ağustos Ayı Ortalama Sicaklık $\left({ }^{\circ} \mathrm{C}\right)$ & $>25$ & $22-25$ & $20-22$ & $<20$ \\
\hline $\begin{array}{l}\text { Topoğrafya } \\
\text { Yükseklik (metre) }\end{array}$ & $0-600$ & $600-800$ & $800-1100$ & $>1100$ \\
\hline $\begin{array}{l}\text { Toprak } \\
\text { Arazi kullanım kabiliyet sınıfları }\end{array}$ & I & I & II & III-VIII \\
\hline Derinlik (cm) & $\begin{array}{l}>90 \\
\text { Derin }\end{array}$ & $\begin{array}{l}50-90 \\
\text { Orta derin }\end{array}$ & $\begin{array}{l}20-50 \\
\text { Siğ }\end{array}$ & $0-20$ Çok sığ \\
\hline
\end{tabular}

$\mathrm{Bu}$ alt kriterlere ait puanlar ile ait olduğu kriterin ağırlık değerleri çarpılarak farklı boyuttaki kriterlerin aynı ölçekte bir arada toplanabilir hale getirilmesi sağlanmaktadır. Tarımsal ürünlere yönelik arazi uygunluk analizlerinde yaygın olarak kullanılan bu yöntemin ifade edildiği eşitlik aşağıda belirtilmiştir.

$$
\mathrm{S}=\sum_{\mathrm{i}=1}^{\mathrm{n}} \mathrm{W}_{\mathrm{i}} \mathrm{X}_{\mathrm{i}}
$$

S: toplam puan;

Wi: kriterin ağırlık değeri;

Xi: alt kriter puan1,

n: toplam kriter sayıs

$\mathrm{Bu}$ eşitlik uygulanarak çalışmada kullanılan kriterlerin almış olduğu değerler hesaplanmış ve (FAO, 1985)' te belirtilen arazi uygunluk sınıf aralıklarına göre standartlaştırılarak soya için arazi uygunluk analizine ait haritalama yapılmıştır (Çizelge 2).

Ana ürün soyaya yönelik arazi uygunluk sınıflarının belirlenmesinde, kullanılan ana kriterlerin (iklim, toprak, topoğrafya) ve bu ana kriterlere ait alt kriterlerin (vejetasyon süresi, etkili sıcaklık toplamı, Temmuz ve Ağustos ayları ortalama sıcaklıkları, yükseklik, Arazi Kullanım Kabiliyet Sınıfları, derinlik sınıfları) etki oranları eşit olmayacağından, her bir kriterin birbirlerine göre önemi göz önünde bulundurularak ağırlık puanları, çok kriterli karar verme yöntemlerinden biri olan Analitik Hiyerarşi Süreci tekniği kullanılarak verilmiștir. Analitik Hiyerarși Süreci, CBS tabanlı uygunluk sınıflamalarına dahil edilmiş en iyi çok kriterli karar verme tekniklerinden birisidir (Jankowski, 1994;
Marinoni, 2004).

Çizelge 2. Ana ürün soya için arazi uygunluk sınıf ve değerleri

\begin{tabular}{cccc}
\hline Sınıf & Tanımlama & Değer & $\begin{array}{c}\text { (FAO;1985) } \\
\%\end{array}$ \\
& & & \\
\hline S1 & Çok uygun & $20.385-25.480$ & $80-100$ \\
S2 & Orta uygun & $15.289-20.384$ & $60-80$ \\
S3 & Az uygun & $10.193-15.288$ & $40-60$ \\
N & Uygun değil & $<10.192$ & $0-40$ \\
\hline
\end{tabular}

Bu teknik 1970'li yıllarda Thomas L. Saaty tarafindan geliştirilmiş olup, kriterlerin ikili olarak birbirleriyle göreceli önemine göre karşılaştırılmalarına dayanmaktadır (Satty, 1980) (Çizelge 3). Bu karşılaştırmalar genellikle konu veya ürün uzmanlarının (karar vericiler) görüşleri ile yapılır. İkili karşılaştırmaları yapan uzman, tanım olarak ifade edilen sözel tercihlere karşıllı gelen sayısal değerleri kullanarak, kriterler için ikili karşılaştırma matrisi oluşturur. Herhangi bir kriterin kendisi ile karşılaştırılmasında verilecek hüküm "eşit derecede öneme sahip" olmalıdır. Yani AHS'de ikili karşılaştırmalar matrisinin köşegenlerindeki tüm elemanlara 1 değeri atanmaktadır. Matris simetrik olduğu için yalnızca matrisin yarısının doldurulması yeterli olmaktadır. Matrisin geri kalan boş hücreleri ikili karşılaştırılması yapılmış hükmün tersinin alınması ile tamamlanır. Bu çalışmada, ana kriterler ve alt kriterler için ayrı ayrı ikili karşılaştırma matrisi oluşturulmuştur (Çizelge 4). 
Çizelge 3. AHS tekniği ikili karşılaştırma ölçeği (Satty, 1980)

\begin{tabular}{cl}
\hline Sayısal değer & Tanım \\
\hline 1 & Öğeler eşit derecede öneme sahiptir. \\
3 & 1. ölçüt 2.'ye göre biraz daha önemlidir. \\
5 & 1. ölçüt 2.'ye göre fazla önemlidir. \\
7 & 1. ölçüt 2.'ye göre çok fazla önemlidir. \\
9 & 1. ölçüt 2.'ye göre olası en kuvvetli öneme sahiptir. \\
$2,4,6,8$ & İki yakın ölçek arasındaki ara değerdir. Uzlaşma gereken durumlarda kullanılmaktadır. \\
\hline
\end{tabular}

Çizelge 4. Ana ve alt kriterler ikili karşılaştırma matrisi ve normalize ağırlık değerleri

\begin{tabular}{lcccc}
\hline \multicolumn{3}{c}{ Ana Kriterler İkili Karşılaştırma Matrisi } & \\
\hline & İklim & Toprak & Topoğrafya & $\begin{array}{c}\text { Normalize } \\
\text { Ağırlık }\end{array}$ \\
\cline { 2 - 5 } İklim & 1 & & & 0.6716 \\
Toprak & 0.111 & 1 & & 0.0629 \\
Topoğrafya & 0.333 & 5 & 1 & 0.2654 \\
\hline$\lambda_{\max }: 3.029 ; R \dot{I}: 0.58 ; T O: 0.03<0.10$ & & & $\sum=1$ \\
\hline
\end{tabular}

Alt Kriterler İkili Karşılaştırma Matrisi

\begin{tabular}{lllllllll}
\hline & 1 & 2 & 3 & 4 & 5 & 6 & 7 & $\begin{array}{l}\text { Normalize } \\
\text { A ğırlık }\end{array}$ \\
\hline 1 & 1 & & & & & & & 0.4053 \\
2 & 0.333 & 1 & & & & & & 0.2823 \\
3 & 0.20 & 0.20 & 1 & & & & & 0.1195 \\
4 & 0.166 & 0.20 & 0.50 & 1 & & & & 0.0897 \\
5 & 0.143 & 0.143 & 0.20 & 0.25 & 1 & & & 0.0401 \\
6 & 0.143 & 0.143 & 0.20 & 0.2 & 0.50 & 1 & \\
7 & 0.125 & 0.143 & 0.25 & 0.50 & 0.50 & 0.333 & 1 \\
\hline$\lambda_{\max }: 7.740 ;$ & Rİ: $1.32 ;$ TO: $0.09<0.10$ & & & & & $\sum=0271$ \\
\hline
\end{tabular}

1:Vegetasyon süresi, 2:Etkili sıcaklık toplamı, 3: Temmuz ayı ortalama sıcaklık, 4: Ağustos ayı ortalama sıcaklık,

5: Yükseklik, 6: Arazi kullanım kabiliyet sınıfları, 7: Derinlik

Matriste oluşturulan ikili karşılaştırma yargılarının tutarlılı̆̆ını ölçmek için üst limit 0.10 olan bir tutarlılık oranı (consistency ratio) kullanılmaktadır (Satty, 1980).

Tutarlılık oranının hesaplanmasında kullanılan Tutarlılık İndeksi (Ti); ikili karşılaştırmalar matrisi ile buna yönelik normalize ağırlık değerlerinin çarpılmasından elde edilen ağırlıklandırılmış toplam vektörün her bir elemanının, buna karşıllk gelen normalize ağırlık değerlerine bölünmesinden elde edilen değerlerin aritmetik ortalaması olan maksimum özdeğerin $\left(\lambda_{\max }\right)$ kullanıldığı aşağıdaki formül ile elde edilmektedir.

$$
\mathrm{T} \dot{\mathrm{I}}=\left(\lambda_{\max }-\mathrm{n}\right) /(\mathrm{n}-1)
$$

Tİ : Tutarlılık indeksi

Çizelge 5. Rastgele indeks değerleri (Satty, 1980)

\section{$\mathrm{n}$ : Karşılaştırılan elemanların sayısı \\ $\lambda \max$ : Maksimum özdeğer \\ Buna göre tutarlılık oranı;}

$\mathrm{TO}=\mathrm{TI} / \mathrm{RI}$

bağıntısı kullanılarak hesaplanmıştır.

TO: Tutarlılık oran

TI: Tutarlılık indeksi

RI: Rastgele indeks

Rastgele indeks; rastgele olarak üretilmiş ikili karşılaştırmalar matrislerinin ortalama tutarlılık indeksini ifade eder. Rİ değerleri, matriste ikili karşılaştırması yapılan elemanların sayısına (n) göre değer alır (Çizelge 5).

\begin{tabular}{llllllllllllllll}
\hline $\mathbf{n}$ & 1 & 2 & 3 & 4 & 5 & 6 & 7 & 8 & 9 & 10 & 11 & 12 & 13 & 14 & 15 \\
\hline $\mathbf{R I ்}$ & 0.00 & 0.00 & 0.58 & 0.90 & 1.12 & 1.24 & 1.32 & 1.41 & 1.45 & 1.49 & 1.51 & 1.48 & 1.56 & 1.57 & 1.59 \\
\hline
\end{tabular}




\section{Bulgular ve Tartışma}

$\mathrm{Bu}$ çalışma kapsamında kullanılan her bir veri setine ait alt kriter katmanları, soya ürün uzmanı görüşleri doğrultusunda belirlenen kriter sınıflarına göre arazi uygunluk sınıfları sayısı oranında, dört kategoride yeniden sinıflandırılarak hücresel veri tipi, raster formatı olarak üretilmiştir (Şekil 3). Birbirine komşu ve aynı hacimdeki piksellerin bir araya gelmesinden oluşan hücresel veride, her pikselin sayısal bir değeri vardır. $\mathrm{Bu}$ sayısal değerler, mekansal uygunluk analizlerinde matematiksel işlemlerle farklı sayısal değerler olarak tanımlanabilir (Esri, 2001). Bu özelliğinden dolayı, Çok Kriterli Karar Verme yöntemlerinde bu farklı tipteki veri katmanlarının değerlendirilmesi ve modellemelerde kullanılması etkin olarak sağlanabilmektedir. AHS tekniğine göre ikili olarak karşılaştırılan ana ve alt kriterler için ağırlık puanları hesaplanmıştır. Ana kriterler için ikili karşılaştırma; tutarlılık oranı 0.03 oranında tutarlı bir matris olarak oluşturulmuştur. $\mathrm{Bu}$ karşılaştırmada, iklimin soya yetiştirilmesinde arazi uygunluk sınıflarının belirlenmesinde en büyük ağırlığa (\% 67.16) sahip olduğu belirlenmiştir. Bunu sırasıyla topoğrafya (\% 26.54) ve toprak (\% 6.29) takip etmiştir. Soyanın yetişebileceği alanlardaki dağılımı üzerinde iklimin uygun yada ne oranda uygun olması durumu, önemli belirleyici unsur olmaktadır (Özçağlar,1988). Çalışma alanının bulunduğu konumu itibariyle, iklimsel farklılıkların fazla yaşanması, soyanın yetiştirilmesinde en önemli kısıtlayıcı unsur olmaktadır. Özellikle çalışmamızda kullandığımız iklim veri setinde bulunan alt kriterler, soya için arazi uygunluk sınıflarının tayininde belirleyici etkiye sahip olmuşlardır. Aynı şekilde topoğrafya da, başta soya olmak üzere genel anlamda tarımsal faaliyetler üzerinde önemli etkiye sahiptir. Topoğrafik farklılıkların değişiklik göstermesi, bitki örtüsü ve bitki türlerinin de alan içerisinde değişiklik göstermesine neden olmaktadır. Bu yüzden topografyanın, bitki örtüsünün dağılışını kontrol eden temel faktör olduğu kabul edilmektedir (Barrio, 1997).

Alt kriterler için ikili karşılaştırma matrisinde 0.09'luk tutarlılık oranıyla tutarlı bir karşılaștırma yapılmıştır. Bu kriterlere ait normalize ağırlık değerleri ele alındığında, 0.4053 ağırlık değeriyle en yüksek ağırlığa sahip alt kriter olarak vegetasyon süresi görülmektedir. $\mathrm{Bu}$ alt kriteri sırasıyla; etkili sıcaklık toplamı (0.2823), Temmuz ayı ortalama sicaklığ (0.1195), Ağustos ayı ortalama sicaklığ (0.0897), yükseklik (0.0401), arazi kullanım kabiliyet sınıfları (0.0358) ve toprak derinliği (0.0271) kriterleri takip etmektedir. Önemli bir ağırlığa sahip olan vegetasyon süresi alt kriteri; Nisan-Eylül ayları arasındaki dönem için geçerli olan yetişme süresi olup, ekim dönemi için sıcaklık eşik değeri Nisan ayında $12{ }^{\circ} \mathrm{C}$ ' ye çıktığı ve hasat dönemi olarak da Eylül veya Ekim aylarında sıcaklığın $15{ }^{\circ} \mathrm{C}$ ' ye düştüğü tarihler dikkate alınarak üretilmiştir. Ülkemizin iklim şartlarına uygun ana ürün soya çeşitleri için yetişme süresi, 120-140 gün arasında değişmektedir (Anonim, 2012). Eylül-Ekim aylarındaki hasat döneminde yaşanabilecek sicaklık düşmeleri veya yağış nedeniyle, bu süre biraz daha uzayabilse de, genel olarak soya tarımına en uygun yerlerde ortalama olarak 130-135 günlük bir süre yeterli olmaktadır. Farklı coğrafi ve iklim bölgelerinde vegetasyon süreleri farklılıklar göstermekte olup, Meena ve ark. (2014)'te, Rajasthan'ın Bundi Bölgesinde soya için arazi uygunluğunun değerlendirilmesi çalışmalarında vegetasyon süresini iklim ana kriterinin bir alt kriteri olarak kullanmışlardır. Buna göre $>120$ gün çok uygun (S1), 100-120 gün orta uygun (S2), 85-100 gün az uygun (S3) ve $<85$ günü ise uygun olmayan $(\mathrm{N})$ sinıf aralıklarında değerlendirmişlerdir.

Etkili sicaklık toplamı ( $\left.\geq 10{ }^{\circ} \mathrm{C}\right)$; soyanın ekimhasat dönemi süresinde eşik $10{ }^{\circ} \mathrm{C}$ ve üstü sıcaklık toplamlarını ifade eden alt kriter olarak üretilmiştir. Vegetasyon süresinin belirlenmesinde sıcaklık etkili olan önemli bir alt parametredir. Yaz dönemi süresince toplam olarak $2400{ }^{\circ} \mathrm{C}$ sicaklığı bulan alanlarda soya yetiştirilebilir (İlisulu, 1973). He ve ark. (2011)'de Çin'de CBS kullanarak yazlık soya yetiştirilen uygun alanların değerlendirilmesi çalışmaları kapsamında $10{ }^{\circ} \mathrm{C}$ eşik değere göre etkili sıcaklık toplamı kriterini; $3300-2800{ }^{\circ} \mathrm{C}$ çok yüksek, $2800-2400{ }^{\circ} \mathrm{C}$ veya $>3400$ ${ }^{\circ} \mathrm{C}$ yüksek, 2400-2000 ${ }^{\circ} \mathrm{C}$ orta, 2000-1000 ${ }^{\circ} \mathrm{C}$ düşük, < $1900{ }^{\circ} \mathrm{C}$ çok düşük uygunluk sınıfları olarak kullanmışlardır. Çalışmada yer alan soya ürün uzmanı görüşlerine göre; Temmuz ayı, ülkemizdeki ana ürün soya ekilişleri için tam olarak çiçeklenme dönemidir. Bu ayda, düşük sıcaklıklar çiçek oluşumunu ve döllenmeyi olumsuz etkilerken, aşırı yüksek sıcaklar da çiçek dökmeyi artırmakta ve dolayısıyla ileriki dönemlerde daha az bakla oluşumu yoluyla, verimi azaltıcı etki yapmaktadır. Ağustos ayı ise, bakla oluşumu ve baklalarda dolumun gerçekleştiği dönem olup, doğrudan verime etki eden bir süreçtir.

Aynı şekilde, düşük sıcaklıklar veya bitkide strese yol açan aşırı sıcaklar, besin maddelerinin dolumunu olumsuz etkileyerek, verimi düşürebilmektedir. Temmuz ve Ağustos ayları için ortalama sıcaklık değerinin $25{ }^{\circ} \mathrm{C}$ olarak standart alınması, bu iki ay boyunca toplam olarak $1500{ }^{\circ} \mathrm{C}$ sicaklığın, yani bitkinin toplam sıcaklık isteğinin yarısının bu iki aylık dönemde karşılanmasını gündeme getirmektedir ki; çiçeklenme, bakla oluşumu ve bakla dolumu devrelerini içeren bitki gelişimi için bu sıcaklık değeri en uygun seviyeyi göstermektedir.

Soyanın 1.5-2 metre derinliğe ulaşabilen kazık köklü bir bitki olması ve ana köke bağlı olarak ayrıca kuvvetli bir saçak kök sisteminin bulunması, toprağın derinliklerine sizan su ya da besin maddelerini de bünyesine alarak, derin topraklardan daha iyi yararlanmasını ve daha fazla verime ulaşabilmesini sağlamaktadır (Nazlıcan, 2006). Bhermana ve ark. (2013)'te tarımsal arazi kullanım planlaması için Endonezya'nın Kalimantan Bölgesinde arazi kaynaklarının bir araya getirilerek değerlendirilmesi 
amacıyla yapmış oldukları çalışmalarında, soya için arazi uygunluk kriterleri olarak aylık ortalama sicaklık

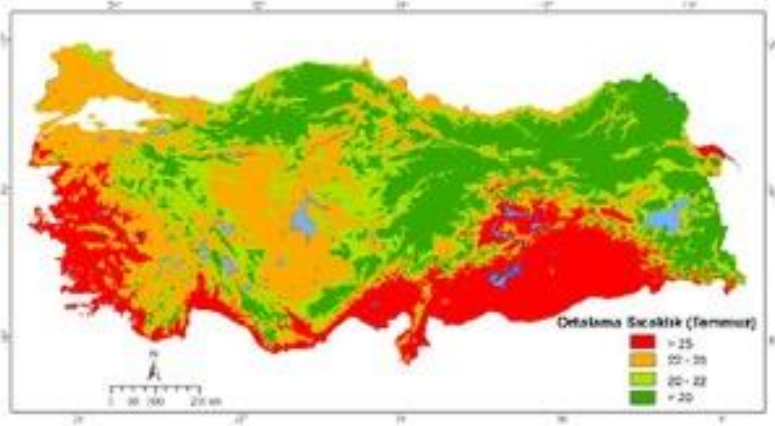

I-Temmuz ayı ortalama sıcaklık

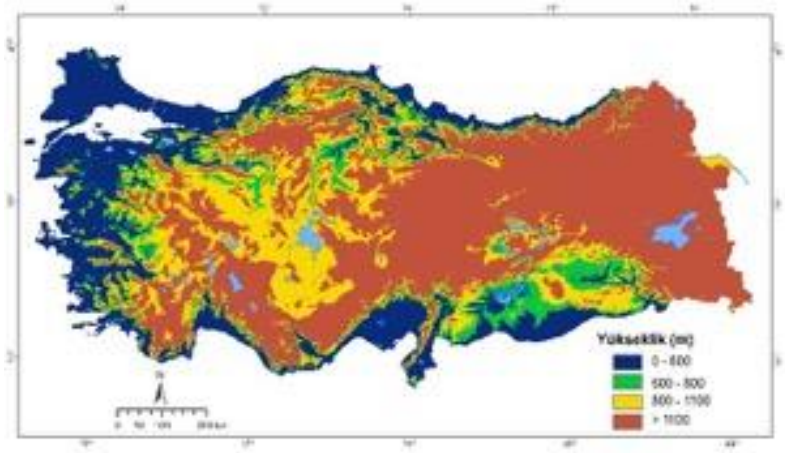

III- Yükseklik

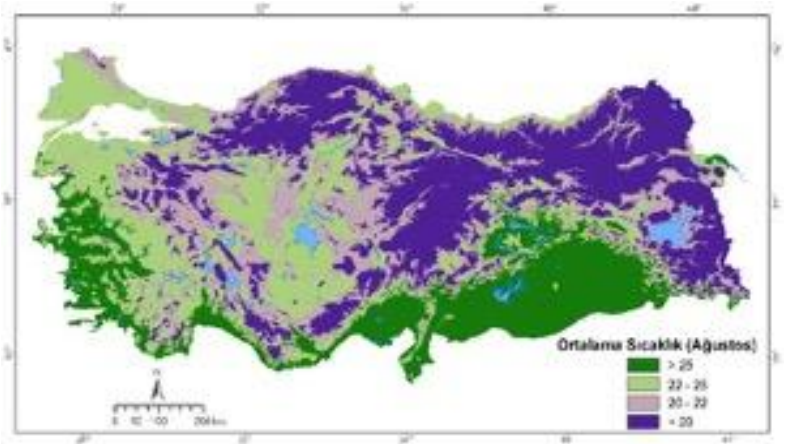

V- Ağustos ayı ortalama sıcaklık ve etkili toprak derinliği kriterlerini kullanmışlardır.

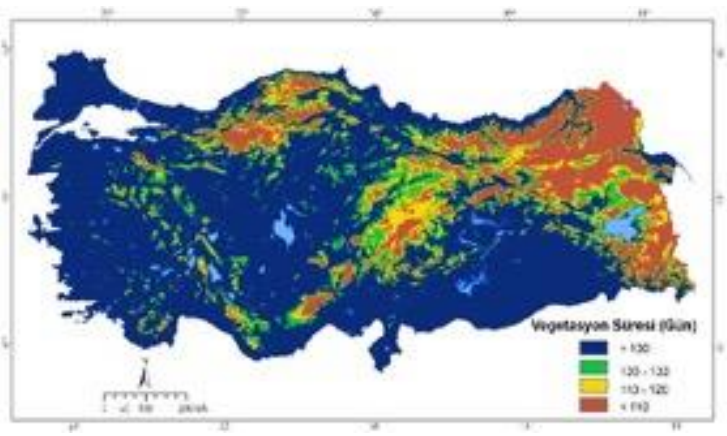

II- Vegetasyon süresi

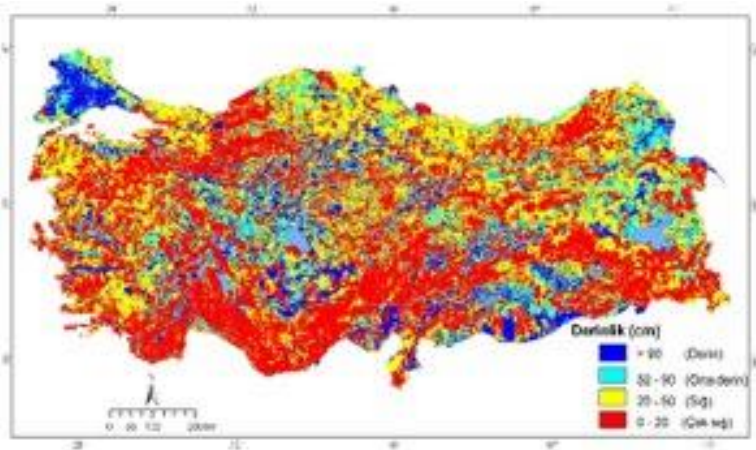

IV- Toprak derinliği

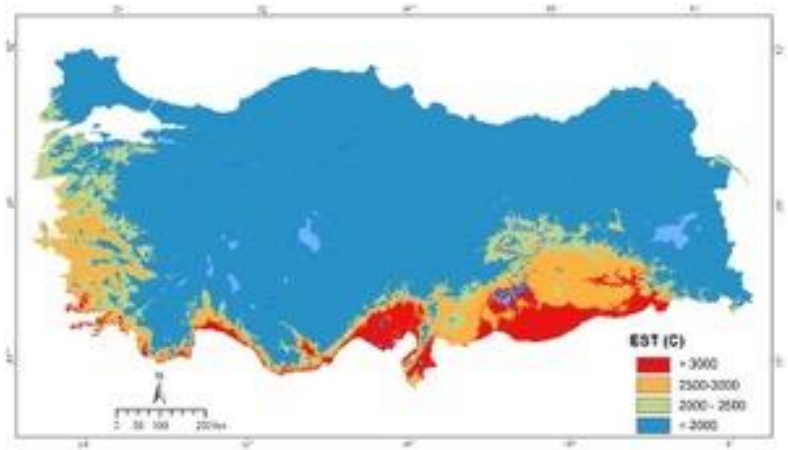

VI- Etkili sicaklık toplamı

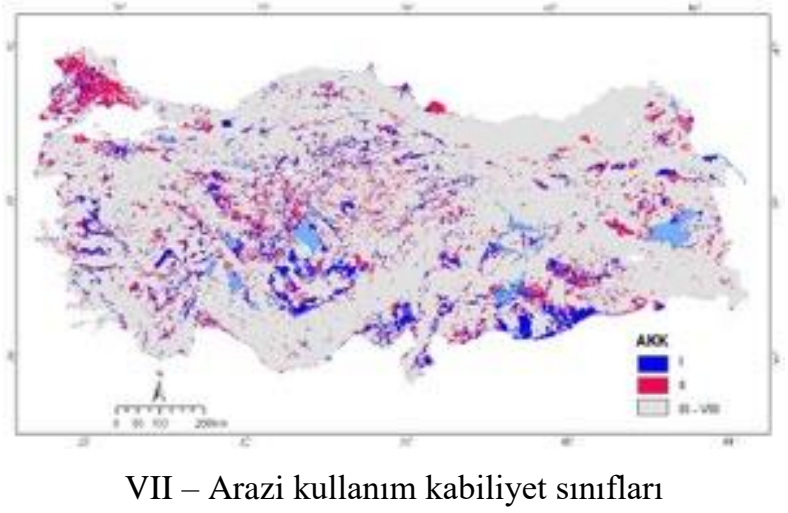

Şekil 3. Ana ürün soya yetiştirilmesi için arazi uygunluk alt kriter katmanları 
Aylık ortalama sıcaklıklar için $23-25{ }^{\circ} \mathrm{C}$ çok uygun (S1), $25-28^{\circ} \mathrm{C}$ orta uygun (S2), $28-32{ }^{\circ} \mathrm{C}$ az uygun (S3), $<18$; $>32{ }^{\circ} \mathrm{C}$ uygun olmayan $(\mathrm{N})$ arazi uygunluk sınıflarını kullanırlarken, toprak derinliği için ise $>75$ $\mathrm{cm}$ çok uygun (S1), 50-75 cm orta uygun (S2), 20-50 $\mathrm{cm}$ az uygun (S3) ve $<20 \mathrm{~cm}$ uygun olmayan $(\mathrm{N})$ kriter sınıf aralıklarını baz almışlardır.

Yükseklik (rakım); soya tarımında önemli kısıtlayıcı etkiye sahip bir kriterdir. Yükseklik arttıkça, soyanın boy ve boğum sayılarında azalışların görüldüğüne yönelik yapılmış çalışmalarda, tohum veriminin düştüğü ve çiçeklenme gün sayısının 3-13 gün, olgunlaşma gün sayısının ise 2-24 gün arasında geciktiği tespit edilmiştir (Basnet, 1974). Behnam ve ark. (2013)'te İran'ın Golestan Bölgesindeki 4 havzada gerçekleştirdikleri çalışmada; soyanın yetiştirilmesi için arazi uygunluk sınıflarının elde edilmesinde, topoğrafik faktörlerden biri olan yükseklik kriterini, deniz seviyesinden 190-397 metre yukarısını eşik değer olarak kullanmışlardır

Çizelge 6. Ana ürün soya yetiştirilmesi için arazi uygunluk sınıflarının bölgeler bazında alansal ve oransal dağılımları

\begin{tabular}{|c|c|c|c|c|}
\hline BÖLGELER & $\begin{array}{c}\text { Çok Uygun } \\
\text { (S1) }\end{array}$ & $\begin{array}{c}\text { Orta Uygun } \\
\text { (S2) }\end{array}$ & $\begin{array}{c}\text { Az Uygun } \\
\text { (S3) }\end{array}$ & $\begin{array}{l}\text { Uygun Değil } \\
\text { (N) }\end{array}$ \\
\hline Akdeniz Bölgesi & $\begin{array}{c}1757337.64 \\
(\% 19.52)\end{array}$ & $\begin{array}{c}694686.63 \\
(\% 7.72)\end{array}$ & $\begin{array}{c}593894.62 \\
(\% 6.60)\end{array}$ & $\begin{array}{c}5955455.25 \\
(\% 66.16)\end{array}$ \\
\hline $\begin{array}{l}\text { Doğu Anadolu } \\
\text { Bölgesi }\end{array}$ & $\begin{array}{c}231486.78 \\
(\% 1.54)\end{array}$ & $\begin{array}{c}730093.80 \\
(\% 4.86)\end{array}$ & $\begin{array}{c}2051002.14 \\
(\% 13.65)\end{array}$ & $\begin{array}{c}12015688.02 \\
(\% 79.95)\end{array}$ \\
\hline Ege Bölgesi & $\begin{array}{c}1455372.72 \\
(\% 16.52)\end{array}$ & $\begin{array}{c}1252917.91 \\
(\% 14.21)\end{array}$ & $\begin{array}{c}1001317.44 \\
(\% 11.36)\end{array}$ & $\begin{array}{c}5105179.26 \\
(57.91)\end{array}$ \\
\hline $\begin{array}{c}\text { Güneydoğu } \\
\text { Anadolu Bölgesi }\end{array}$ & $\begin{array}{c}2800682.15 \\
(\% 36.95)\end{array}$ & $\begin{array}{c}1253025.93 \\
(\% 16.53)\end{array}$ & $\begin{array}{l}17006.49 \\
(\% 0.22)\end{array}$ & $\begin{array}{c}3509541.00 \\
(\% 46.30)\end{array}$ \\
\hline Karadeniz Bölgesi & $\begin{array}{c}726614.88 \\
(\% 6.18)\end{array}$ & $\begin{array}{c}1030515.72 \\
(\% 8.75)\end{array}$ & $\begin{array}{c}1531533.94 \\
(\% 13.01)\end{array}$ & $\begin{array}{c}8481400.12 \\
(\% 72.06)\end{array}$ \\
\hline İç Anadolu Bölgesi & $\begin{array}{c}28782.11 \\
(\% 0.15)\end{array}$ & $\begin{array}{c}2317206.70 \\
(\% 12.47)\end{array}$ & $\begin{array}{c}6671811.41 \\
(\% 35.86)\end{array}$ & $\begin{array}{c}9586215.71 \\
(\% 51.52)\end{array}$ \\
\hline Marmara Bölgesi & $\begin{array}{c}2292087.44 \\
(\% 31.58)\end{array}$ & $\begin{array}{c}864292.12 \\
(\% 11.90)\end{array}$ & $\begin{array}{c}283123.60 \\
(\% 3.90)\end{array}$ & $\begin{array}{c}3819728.47 \\
(\% 52.62)\end{array}$ \\
\hline Alan (ha) & 9292363.72 & 8142738.81 & 12149689.64 & 48473207.83 \\
\hline Oran (\%) & $\% 11.91$ & $\% 10.43$ & $\% 15.56$ & $\% 62.10$ \\
\hline
\end{tabular}

AKK sinıfları; arazilerin tarımsal açıdan planlamalarında kullanılan, soyanın isteklerini karşılayabilecek nitelikteki sınıfları ile önemli bir kriter olarak değerlendirimiştir. Soyanın, hem bir çapa bitkisi olarak sıkça makineyle işleme ihtiyaç duyması ve hem de sulamanın sağlıklı biçimde yapılabilmesi bakımından, düşük eğimli ve toprak derinliği fazla olan I. sınıf arazilere daha çok gereksinim duymaktadır. Buna göre, soya tarımı için en uygun ve orta uygun yerler için I. sınıf tarım arazilerinin, az uygun yerler için II. sınıf tarım arazilerinin, hiç uygun olmayan alanlar için ise III ile VIII arası sınıflara sahip tarım arazilerinin cevap verebileceği belirlenmiştir.

Ana ve alt kriterler, AHS tekniği kullanılarak atanan normalize ağırlık değerleri oranında ağırlıklandırılmış doğrusal kombinasyon yöntemine göre biraraya getirilmiş ve çalışma alanında ana ürün soya için arazi uygunluk sınıfları haritası oluşturulmuştur (Şekil 4). Bu sınıfların çalışma alanındaki toplam ve bölgesel bazlı alansal ve oransal dağılımları belirlenmiștir. Arazi uygunluk sınıflarının bölgesel bazlı dağılımlarında, her bölgenin kendi alanları içerisindeki alansal ve oransal dağılımları ifade edilmektedir (Çizelge 6).

Buna göre; soya yetiştirilmesi için çok uygun (S1) arazi sinıfinda 2800682.15 hektar alan ile en fazla alana sahip Güneydoğu Anadolu Bölgesi olurken, bunu Marmara Bölgesi (2 292087.44 hektar), Akdeniz Bölgesi (1 757337.64 hektar) ve Ege Bölgesi (1 455 372.72 hektar) takip etmektedir. Buna karşılık soya 


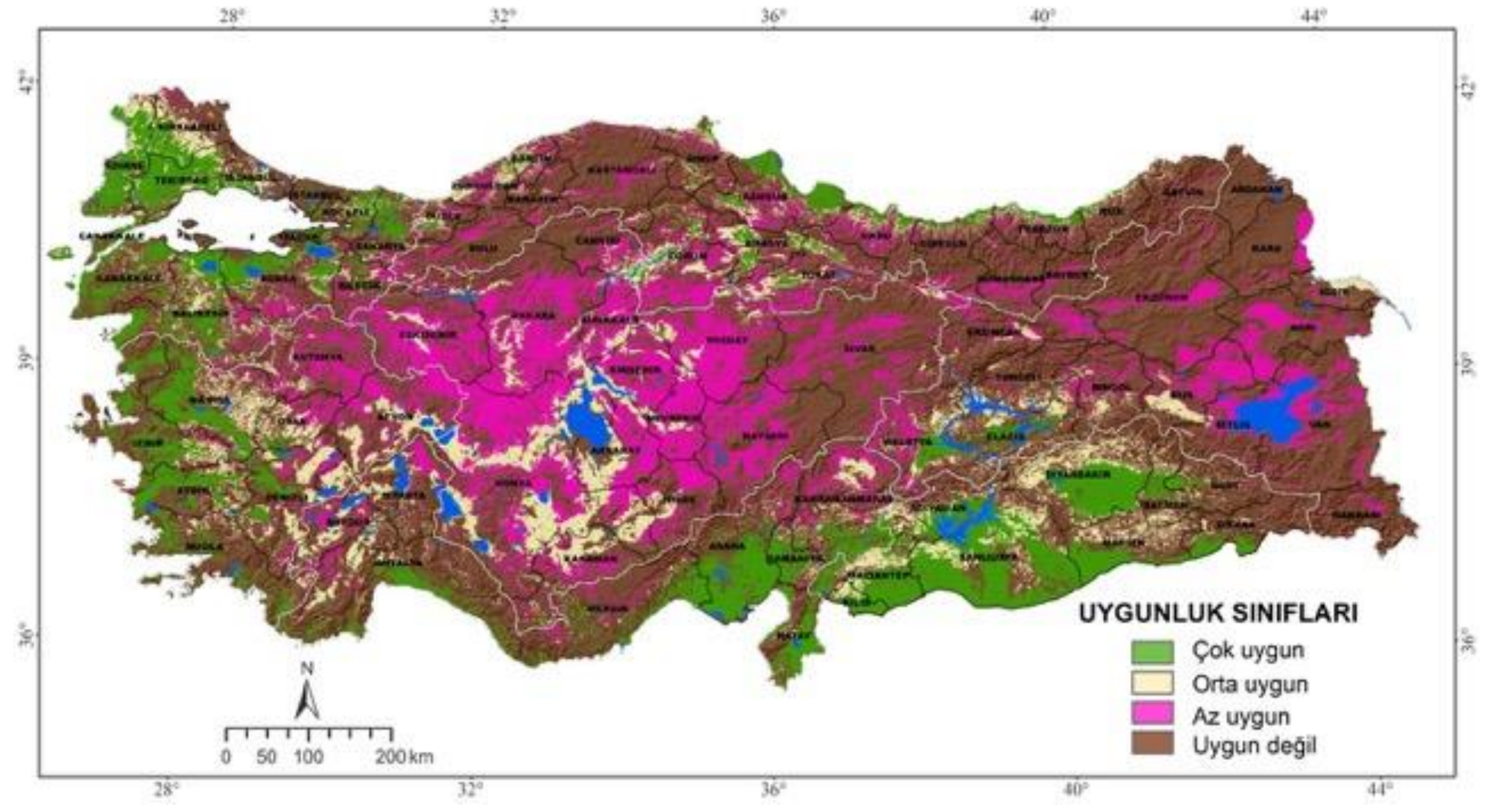

Şekil 4. Türkiye'de ana ürün soya yetiştirilmesi için arazi uygunluk haritası 
yetiştirilmesine uygun olmayan $(\mathrm{N})$ arazi sınıfında Doğu Anadolu Bölgesi 12015688.02 hektar alan ile en fazla hektar) takip etmektedir. Arazi uygunluk sinıflarının çalışma alanının genel dağılımında; toplam alanın \% 11.91 'i (9 292363.72 hektar) çok uygun (S1) sınıfta yer alırken, \% 10.43'ü ( 8142738.81 hektar) orta uygun (S2), \% 15.56's1 (12 149689.64 hektar) az uygun (S3) ve \% 62.10'u (48 473207.83 hektar) ise uygun olmayan (N) sınıflar içerisinde yer almaktadır.

\section{Sonuç}

Ana ürün soya yetiştirilmesi için arazi uygunluk sınıflarının analizine yönelik yapılan bu çalışmada, kullanılan yöntem ve tekniklerin sağladığı kolaylıklar ile ülkesel boyutlu, geniş hacimli, çok sayıdaki veri tiplerinin bir araya getirilmesi sağlanmış ve ürüne yönelik ihtiyaç duyulan gerekli analizler neticesinde bazı tespitlerde bulunulmuştur. Buna göre; genellikle kıyı ovalarının ve 700-800 metre rakımın altındaki iç bölge ovalarının, ana ürün soya yetiştirilmesi için en uygun alanlar olarak çıktığı görülmektedir. Soya üretim alanlarını sinırlayan en önemli parametreler olan vejetasyon süresi, Temmuz-Ağustos ayları ortalama hava sıcaklıkları ve rakım gibi değerlerin, harita üzerindeki uygunluk sınıflarının dağılımlarının oluşmasında daha önemli etkiler yaptığı açıktır. Ana üründe, yüksek verim için daha geççi çeşitlerin tercih edilmesi sebebiyle, 130 günün üzerinde bir yetişme süresine ihtiyaç duyulması, ayrıca çiçeklenme ve bakla bağlama dönemleri için gerekli en uygun sıcaklık değeri olan $25-30{ }^{\circ} \mathrm{C}$ şartını sağlayacak bir iklim uygunluğuna sahip olunması ve 800 metrenin altındaki düşük rakım değerlerinin gerekliliği, haritada belirlenen en uygun soya ekim alanlarının dağılımını sınırlandırmaktadır.

Günümüzde en fazla soya üretiminin gerçekleştirildiği yer olarak bilinen Çukurova Bölgesi, dağlık alanlar dışında kalan geniş ovalarının tamamında, ana ürün soyaya en uygun alan olarak çıkmıştır. Sulama imkanına da sahip olan Çukurova'da $400-450 \mathrm{~kg} \mathrm{da}^{-1}$ verim seviyelerine ulaşılması ve önemli soya üreticisi ülkelere göre de daha fazla verim potansiyelinin söz konusu olması, Çukurova Bölgesi'ni soya için adeta vazgeçilmez bir alan haline getirmektedir.

Güneydoğu Anadolu Bölgesi, soyaya iklim uygunluğu sayesinde, Çukurova'dan 3-4 kat daha fazla bir potansiyel üretim alanı sunmaktadır. Güneydoğu Anadolu Projesi (GAP) kapsamında sulanan alan miktarının artmasına paralel olarak, soya ekim alanlarının da bu bölgede artması beklenmektedir. Karadeniz Bölgesinde, başta Samsun ili olmak üzere, Doğu Karadeniz kıyı ovalarında ana ürün soya için uygun alanlar olduğu ve yaz yağışlarının yeterli seviyelerde gerçekleştiği alanlarda sulamaya gerek kalmadan da yetiştirilebileceği; Ege ve Marmara Bölgeleri ovalarında da sulama imkanının bulunması ölçüsünde soya yetiştiriciliğinin başarıyla yapılabileceği, yapılan bu çalışmada elde edilen alana sahip olurken, bunu İç Anadolu Bölgesi ( 9586 215.71 hektar) ve Karadeniz Bölgesi (8 481400.12 uygunluk sınıflarının dağılımlarından anlaşılmaktadır.

İklim ve rakım değerlerinin sınırlayıcı etkilerine bağlı olarak, özellikle Doğu Anadolu Bölgesinin büyük bir kısmının soya yetiştiriciliği için uygun olmadığı, İç Anadolu Bölgesinde ise sadece Konya ovasının orta uygun sınıfında yeraldığı tespit edilmiştir. Gelecekte, sulama imkanlarının artması ve daha erkenci çeşitlerin geliştirilmesi durumunda, şu anda orta uygun veya az uygun olarak belirlenen alan dağılımlarında da, soya lehine bazı değişimlerin olacağı umulmaktadır.

Sonuç olarak, en azından soya ithalatına gerek kalmayacak miktarda bir yerli soya üretimine kavuşmak adına; ortalama yıllık soya ihtiyacımız olan 2 milyon tonluk (Anonim, 2014) üretim rakamını elde edebilmek için, yaklaşık olarak 400 - 500 bin hektarlık bir ekim alanına ihtiyaç duyulacağı düşünülmektedir. Yerli soya üretimimizin yaklaşık 2/3'ünün buğday sonrasında 2 . ürün soya ekimiyle karşılandığı düşünülürse, ana ürün soya üretimi için 150-200 bin hektarlık bir alanın bile yeterli olabileceği hesaplanabilir. Bu çalışma sonrasında ortaya konulan en uygun ve özellikle de sulama imkanına sahip olan alanlarda, yerli soya üretimi için gerekli üretim desteklerine devam edilmesi durumunda, ümit edilen üretim artışlarını geçekleştirebilmek de mümkün olabilecektir.

\section{Kaynaklar}

Anonim, 2012. Tarım Teknolojisi. Yağ Bitkileri Yetiştiriciliği (Soya ve Yer Fistığı) Modülü. Ankara

Anonim, 2014. www.millermagazine.com/dunya- soya-pazarive-turkiye/.html (Erişim Tarihi : 14.12.2017)

Anonim, 2015. İstatistik Bölümü İnternet Sitesi, http://www.fao.org (Erişim tarihi : 05.12.2017)

Barrio, Gd., Alvera, B., Puigdefabregas, J., and Diez, C., 1997.Response of high mountain landscape to

topographic variables: central pyrenees, Landscape Ecology, $12,95-116$.

Basnet, B., Mader, E.L., Nickell, C.D., 1974.Influence of Altitude on Seed Yield and Other Characters of Soybeans

Differing in Maturity in Sikkim (Himalayan Kingdom). Agronomy Journal, 66: 531-533.

Behnam, K., Mohammad, A.D., Jaime, A.T.S., (2014).Assessment of land suitability and the possibility and

performance of a canola (Brassica napus L.) - soybean (Glycine max L.) rotation in four basins of Golestan province, Iran. National Authority for Remote Sensing and Space Sciences The Egyptian Journal of Remote Sensing and Space Sciences 17, 95-104

Bhermana, A., Sunarminto, B.H., Utami, S.N.H.U., and Totok Gunawan, T., (2013). The Combination of Land

Resource Evaluation Approach and Gis Application To Determine Prime Commodities For Agricultural Land Use Planning At Developed Area (A Case Study Of Central Kalimantan Province, Indonesia). ARPN Journal of Agricultural and Biological Science. Vol. 8, No. 12, December. Indonesia.

Chen, Y., Khan, K., and Padar, Z., 2008. Irrigation 
intensification or extensification assessment: a GISbasedspatial fuzzy multi-criteria evaluation. In: Proceedings of the 8th international symposium on spatial accuracy assessment in natural resources and environmental sciences, 25-27 June, Shanghai, P.R. China, 309-318.

ÇEM, 2011. Kurak ve Yarı Kurak Alan Yönetimi Çalıştayı Sonuç Bildirgesi ve Bildiriler, ISSN 978-605-4610- 04-4, 5-8 Aralık, Ürgüp, Nevşehir.

Eastman, J.R., 1999. IDRISI 32 Guide to GIS and image processing. Clark Labs,Clark University, Worcester, MA,USA.

Esri, 2001. ArcGIS9 Desktop Software, Help References, Working with ArcGIS Spatial Analyst, Esri.

FAO AMIS, 2015. Agricultural Market Information System.

FAO, 1985. Guidelines land evaluation for irrigated agriculture F.A.O., Rome.

Farr, T.G., and Kobrick, M., 2000. Shuttle radar topography mission produces a wealth of data, EOS Transactions AGU, 81: 583-585.

Gençtan, T., 2009. Türkiye'de çeltik üretimi ve sorunları. I. Ulusal Çeltik Sempozyumu, Tekirdağ, Turkey (in Turkish).

He, W., Yang, S., Guo, R., Chen, Y., Zhou, W., Jia, C., and Sun, G., 2011. Gis- Based Evaluation of Soybean

Growing Areas Suitability in China. Part III. International Federation for Information Processing AICT 346: 357366.

Hutchinson, M.F., 1995. Interpolating mean rainfall using thin plate smoothing splines. Int. J. Geogr. Info. Systems, 9: 385-403.

İlisulu, K., 1973. Yağ Bitkileri ve Islahı, s.192,İstanbul.

Jankowski, P., Richard, L., 1994. Environment and planning B, 21 (3): 326-339.

Kihoro, J., Bosco, N.J., and Murage, H., 2013. Suitability analysis for rice growing sites using a multicriteria evaluation and GIS approach in great Mwea region, Kenya. SpringerPlus, 2:265

Li, D., Lui, Y., and Chen, Y., 2011. G1s based evaluation of Soybean growing areas suitability in Chine. International Feceration for Information Processimg, 357-366.

Maddahi, Z., Jalalian, A., Zarkesh, M.M.K., and Honarjo, N., 2014. Land suitability analysis for rice cultivation using multi criteria evaluation approach and GIS. European Journal of Experimental Biology, 4 (3): 639-648.

Malczewski, J., 1999. GIS and multi-criteria decision analysis. Wiley, New York, USA.

Malczewski, J., 2006. GIS-based multicriteria decision analysis: a survey of the literature. Int. J of Geog In Sci 20:703-726.

Marinoni, O., 2004. Computers and geosciences,30 (6): $637-$
646.

Meena, G.L., Singh, R.S., Meena, S., Meena, R.H., and Meena, R.S., (2014). Assessment of land suitability for soybean (Glycine max) in Bundi district, Rajasthan. Agropedology, 24 (2): 146-156. India

MGM, 2017. Internet sitesi https://www.mgm.gov.tr/veridegerlendirme/yillik-toplamyagis-verileri.aspx (Erişim tarihi : 04.01.2018)

Mustafa, A.A., Singh, M.,. Sahoo, R.N., Ahmed, N., Khanna, M., Sarangi, A., and Mishra, A.K., 2011. Land Suitability Analysis for Different Crops: A Multi Criteria Decision Making Approach using Remote Sensing and GIS," Researcher, 3(2): 61-84.

Suitability Analysis for Different Crops: A Multi Criteria Decision Making Approach using Remote Sensing and GIS. http://www.sciencepub.net/researcher, 3(12). (Erişim tarihi : 20.12.2017)

Nazlıcan, A.N., 2006.Soya Yetiştiriciliği Çukurova Tarımsal Araştırma Enstitüsü, Adana. (https://arastirma.tarim.gov.tr/cukurovataem/Belgeler/Yeti stiricilik/soya-yetistiriciligi_1.pdf) (Erişim tarihi : 17.01.2018)

Özçağlar, A., 1988. "Türkiye'deki Tarım Alanlarının Coğrafi Dağılışının Doğal Çevreyle İlişkisi.” Coğrafya Araștırmaları Dergisi, S:11,s:131-150, Ankara.

Patrono, A., 1998. Multi-Criteria Analysis and Geographic Information Systems: Analysis of Natural Areas and Ecological Distributions. Multicriteria Analysis for LandUse Management, Edited by Euro Beinat and Peter Nijkamp, Kluwer Academic Publishers, Environment and Management, 9: 271- 292, AA Dordrecht, The Netherlands.

Pertziger, F., and De Pauw, E., (2002). CLIMAP. An Excelbased software for climate surface mapping. ICARDA, Aleppo, Syria.

Pirbalouti, A.G., 2009. GIS-based land suitability evaluation for rapeseed oil crop. Journal of Food, Agriculture \& Environment, 7(3\&4) : 837 - 840. Helsinki, Finland.

Saaty, T.L., 1980. The Analytic Hierarchy Process. McGrawHill, New York.

TUİK, 2014. http://www.tuik.gov.tr (Erişim Tarihi : 26.01.2018)

Türkeş, M., 1998. "Karadeniz Yağışları”, Bilim ve Teknik, Say1:364: 58-59.

Yu, J., Chen, Y., Wu, J.P., 2009.Cellular automata and GIS based land use suitability simulation for irrigated agriculture, 18th world IMACS/MODSIM Congress, 1317 July, 2009, Cairns, Australia.

Yu, J., Chen, Y., Wu, J.P., 2011. International journal of geographical information science, 25(1): 131-148. 